\title{
Restructuring the Reduced Emissions from Deforestation and Forest Degradation (REDD+) Mechanism for a Post Kyoto Agreement
}

\author{
Kamleshan Pillay*, Lisa Frost Ramsay \\ School of Agriculture, Earth and Environmental Sciences, University of KwaZulu-Natal, Durban, South Africa \\ Email: " pillay.kamleshan@gmail.com
}

Received 18 February 2015; accepted 9 March 2015; published 12 March 2015

Copyright (C) 2015 by authors and Scientific Research Publishing Inc.

This work is licensed under the Creative Commons Attribution International License (CC BY).

http://creativecommons.org/licenses/by/4.0/

(c) (i) Open Access

\begin{abstract}
With the possibility of a new climate agreement being formed in 2015 at COP 21 in Paris, there is a vital need to restructure REDD+ for formal inclusion into such an agreement. There are two vital questions that need to be assessed if REDD+ is to be effective as a policy tool within the United Nations Framework Convention on Climate Change (UNFCCC). First, can REDD+ be financially selfsustaining if it remains as a fund based mechanism or will a market based system be more effective? Second, will REDD+ remain primarily a carbon offsetting mechanism or can it also deliver co-benefits (poverty alleviation, biodiversity conservation, and promoting indigenous rights protection)?
\end{abstract}

Keywords

CDM, Climate Change, Forest, Post Kyoto, REDD+, UNFCCC

\section{Introduction}

Reduced Emissions from Deforestation and Forest Degradation (REDD+) can be described as a PES (payment for ecosystem services) mechanism that involves remuneration in exchange for the protection of forest for carbon sequestration and storage [1]. The ideology behind REDD+ is that without the mechanism, there would be increases carbon emissions to atmosphere. This assumption is important as it is these emissions that serve as a baseline to measure the effectiveness of the REDD+ mechanism. If the proposed emissions are below the refer-

${ }^{*}$ Corresponding author.

How to cite this paper: Pillay, K. and Ramsay, L.F. (2015) Restructuring the Reduced Emissions from Deforestation and Forest Degradation (REDD+) Mechanism for a Post Kyoto Agreement. American Journal of Climate Change, 4, 69-76.

http://dx.doi.org/10.4236/ajcc.2015.41007 
ence level, then the reductions are considered to be "additional” and carbon credits are awarded on this basis. Demonstrating additionality is a major stumbling block of the REDD+ mechanism and requires stringent monitoring, reporting and verification (MRVs) based on recognized standards [2]. It is only after projects are subjected to these rigorous processes that they can be sold and traded on the market.

It must be noted that REDD+ is an expanded mechanism from RED, which did not include the conservation of forests, enhanced forest management and the sequestration benefits of reforestation and afforestation projects [3]. Furthermore, REDD+ has been expanded in terms of its implementation; it was initially used to protect particular forest types in a localized context rather than a fund based mechanism on a national scale [2]. REDD+ is now increasingly considered to be integral to a new climate agreement in Paris in 2015 as, if restructured, it can deliver benefits on all pillars of sustainability. The co-benefits of REDD+ projects include the protection of biodiversity, boosting local economies by providing employment and thereby the improvement of rural livelihoods of those who live close to the forest, and maintaining cultural practices of forest dwelling indigenous people [4].

Despite the acknowledgement that a refined REDD+ structure has benefits and co-benefits if implemented, REDD+ projects have not been recognized as activities under the UNFCCC's Clean Development Mechanism (CDM) [5]. It was thought initially that the REDD+ programme would provide developed countries compliance carbon credits to meet their emission reduction targets of the Kyoto Protocol [6]. However, this has not materialized. Furthermore, it was thought REDD+ would have the structure to correct for market failures and externalities that had resulted from degradation and deforestation of forests [2]. REDD+, however, remains a voluntary PES [7]. Sixty four developing countries were engaged in REDD+ projects in 2009 and while there have been cases of funding from the private sector, most funds have been generated through bilateral agreements most notably between the Scandinavian countries and Indonesia and Brazil [8]. The funding mechanism has remainedself-sustaining despite not being included in formal legislation of the UNFCCC but could arguably be enhanced if changed from a fund based mechanism (PES) to a market based mechanism (Clean Development Mechanism, for example). Since 2011, bilateral agreement partnerships have managed to raise \$8 billion dollars and establishment of a market-based structure could establish further fund opportunities [2]. This paper aims to assess REDD+ currently and provide insights into how the mechanism could be restructured to promote its overall effectiveness as mitigation option with functioning co-benefits.

\section{Structural Flaws of the REDD+ Mechanism}

Forests are of vital concern as they are able to sequester and store carbon; furthermore they are recognized globally as biodiversity hotspots [6] [9]. A reduction in deforestation and degradation of forests has multiple benefits, including the maintenance of carbon sequestration capacity and conservation of biodiversity and ecosystem services. Furthermore, reductions in deforestation can facilitate the movement towards a green economy [10] through effective stakeholder benefits and increased developed-developing country cooperation.

Major flaws of the REDD+ mechanism include definitional issues, leakage, reference levels, permanence, Monitoring, Reporting and Verification (MRVs) and finance availability [6] [9] [11]. Definitional issues include the fundamental question of “what defines a forest?” REDD+ does not distinguish between plantations and natural forest. As suggested by Hartley [12] plantations and forests cannot be thought of as similar. Even though, there is a misconception amongst forest managers and conservationists that plantations are less ecologically diverse than natural forests, they may still possess substantial components of biotic diversity across many taxa [12]. Despite this substantial biodiversity, the ecosystem may still be less resilient as a whole, and therefore provide less ecosystem services. Fast growing plantations that are mostly monoculture in nature are of particular interest. These plantations tend to deplete resources faster than indigenous vegetation although they do grow faster which is of great concern in water scarce areas [13].

Leakage is also a concern related to the REDD+ mechanism and refers to an increase of emissions in one place while reducing emissions in another [2]. African communities using other vegetation types (savanna, thicket and woodland) for fuel while being paid by a REDD+ scheme to maintain the forest biome is an example of leakage. There is also a concern of which reference level should be used to measure emission reductions (that is the level of emissions in the absence of reductions from a REDD+ scheme) and whether this should be country-specific as determined by the UNFCCC [9]. Reference levels are also needed to determine which countries should be of greater focus in REDD+ schemes: countries that have high deforestation rates will benefit more than countries that possess high forest cover and low deforestation rates [2]. Permanence is also an important 
factor in determining how successful a REDD+ scheme will be; if there is anthropogenic pressure to convert forest that is being protected then it is vital that funding mechanism provide adequate long term compensation to the communities that can benefit from using the forest in a destructive manner [6]. It is therefore difficult to determine the time scale that funding needs to be supplied for that would ensure that forests stay standing.

REDD+ MRV methodologies that are more stringently designed could increase the likelihood of the mechanism's inclusion in a post-Kyoto agreement. REDD+ leaves room for corruption and potential carbon leakage and the process lacks transparency and accountability [2]. MRVs currently need to meet the requirements of the major fund contributors however if included in a new International Environmental Agreement (IEA), this would need to be managed by the UNFCCC. Remote sensing has been the most useful tool in mapping forest coverage and carbon stocks however it has its limitations particularly when differentiating between different forest types [14]. This can be resolved using LIDAR and hyper-spectral remote sensing although this is costly and not available to all host countries [15]. With the acknowledgement of capacity building (mostly technological) being a major problem in providing MRV, there have been initiatives by the World Bank and Food and Agriculture Organization (FAO) to increase these technologies [2]. Carbon accounting has improved significantly with the aid of new technologies and this is the key to forest based projects being included in a fund or market based mechanism.

A significant concern with REDD+ is the availability of finance [9]. Fund mechanisms tend to be transient and are particularly dependent on relations between countries [11]. A break down in cooperation between funders and recipients can lead to rapid deforestation. Further, the implementation system of REDD+ requires sufficient monitoring by funders as compensation needs to be used for social upliftment and not monopolised by a few in the community. Land ownership and rights are extremely complicated, particularly in Africa, with much land being owned by tribal authorities. This does not facilitate financial transfers easily and requires stringent screening to ensure that funds are used appropriately [16].

Some REDD+ schemes ignore the overall goal of mitigation in favor of promoting better environmental practices [6]. By promoting protection of younger forest, which have increased carbon sequestration potential, and favoring indigenous forest protection rather than plantations, REDD+ can aid in preserving ecosystem services. Albeit beneficial for the environment, such schemes are not in line with the proposed legally binding agreement in 2015 in Paris at COP21 [17]. However, this view was opposed by Venter et al. [18], where it was suggested that a shift away from a purely carbon emission reduction approach would be beneficial.

\section{REDD+ and Biodiversity}

The mechanism of REDD+ allows for the preservation of forest, not only protecting the carbon storage capacity of forests but also the carbon sequestration potential of forests [19]. It has been argued that the REDD+ mechanism should pay more attention to tropical forest than temperate and subtropical forest owing to the enhanced carbon storage and sequestration potential [20]. Tropical forests can be classified into two types-dry and humid. Globally, tropical forests have a combined areal coverage of 18.5 million $\mathrm{km}^{3}$ storing $248 \mathrm{Gt}$ of organic carbon (this is the equivalent of total fossil fuel emissions since the industrial revolution) [21]. According to Venter and Koh [2] deforestation and degradation releases approximately 1.22 - 1.30 PgC per year and 0.30 PgC per year from peat degradation. The preservation of forest is extremely important as it is responsible for storing $15 \%$ of anthropogenic carbon emissions.

A major concern of the REDD+ mechanism is whether it can deliver the preservation of biodiversity while delivering emission reductions. Tropical forests and coral reefs are widely recognized as ecosystems with the highest levels of biodiversity per unit area and are commonly referred to as "biodiversity hotspots" [2]. Biodiversity is extremely important in maintaining the overall stability of a biological system; reducing species, keystone or not, increases the likelihood of a system undergoing a permanent regime shift and being unable to recover [22].

During the Copenhagen COP in 2009, REDD+ was accused of being a mechanism that was not fully understood particularly the "technical, political and institutional challenges" [3]. This misconception can be attributed to the widely accepted view that the REDD+ mechanism is primarily aimed at carbon storage. Initially it was thought that REDD+ would benefit biodiversity and this was attractive as it allowed the mechanism to have carbon mitigation potential while protecting multiple ecosystem services [2]. However, it was later realized that REDD+ could have a negative effect on biodiversity where the complexity of forests were ignored and the 
mechanism's simplistic nature mostly addresses quantitative aspects of forest preservation (carbon storage) rather than qualitative concerns (biodiversity and resilience) [23].

There are other major concerns about REDD+. These include negative effects on biodiversity associated with the conversion of degraded forests into commercial tree plantations, pressure on non-forest ecosystems with high biodiversity and the inclusion of "sustainable management of forests" when there is no common definition and knowledge of what "sustainable" is [20]. These are of particular concern as it goes against the objectives and principles of the Convention on Biodiversity (CBD). Commercial tree plantations are of particular concern; monoculture plantations normally promote the usage of alien invasive plants owing to their enhanced growing rates [24]. These "carbon farms" not only outcompete indigenous trees but only compromise other ecosystem services such as ground water supply and soil fertility [25]. Venter and Koh [2] also refer to short time period of REDD+ schemes which are simply inadequate at addressing conservation of long lived species. The pressures on non-forest ecosystems that have high biodiversity are of extreme concern. In poorer developing countries, there is an obvious attraction to remove vegetation that is not included in the REDD+ scheme definition of forest, and replant "monoculture carbon farms" [26]. Also, existing data for the monitoring of land use and land covers are scarce in certain developing countries hence evaluation of areas prior to the implementation of REDD+ can be problematic.

There have been suggestions made to counter the possible negative impacts of REDD+ on biodiversity namely improved biodiversity monitoring, policy safeguards for biodiversity and changing the technicalities with the REDD+ mechanism so that carbon storage is equally important as biodiversity preservation within forests [6] [27]. Even though REDD+ must address concerns of biodiversity, if it is to be included as a mechanism in a post-Kyoto IEA, then carbon storage must be the primary objective. Unfortunately, there has not been enough integration of conservation science into policy analysis. The suggestions that have been made include systematic conservation planning to identify which areas REDD+ schemes would deliver the most benefit. Venter and Koh suggest this could be done by promoting the conservation of biodiversity hotspots [2].

Definitional issues of "forests" are also problematic in the context of biodiversity protection as it determines which areas qualify for funds but more importantly will inhibit natural forests being converted into plantations [20]. Lastly, reference levels, leakage and financing of REDD+ need to be altered to promote biodiversity protection. Reference levels are important as they allow for effective MRV of emissions from the REDD+ scheme and also determines which countries are more suitable for participation (countries that have high deforestation rates). REDD+ will not only have to integrate biodiversity conservation while delivering emission reductions; it will have to also control other factors that affect species loss in forests namely, fire, hunting and illegal logging [28] [29]. Other options that are worth mentioning include the implementation of biodiversity credits (market based) that could be linked to the carbon credits [30]. Furthermore, conservation funds have also been mentioned as a possible method to provide funds to conservation of biodiversity while providing emission reductions [31]. It is estimated that $\$ 1.5$ billion dollars would be needed annually for REDD+ schemes globally; it is possible that a market based system for biodiversity credits linked to a carbon based market could generate these funds [32].

\section{REDD+ versus CDM}

REDD+ has received support in the climate policy arena as being a savior [27] [33]-[35]. However, the REDD+ project as a voluntary fund based mechanism leaves much to be desired for potential discussions about the integration of REDD+ into the CDM programme of the UNFCCC [28]. Forestry projects have not been well supported within the CDM programme with only $0.54 \%$ of total projects representing afforestation and reforestation projects [2]. It must be clearly acknowledged that the CDM programme does not support projects that avoid deforestation as in the REDD+ project so it possible that the proportion of forestry projects could grow if forestrelated projects were more broadly defined [28]. Thomas et al. [36] described the major inhibiting factors of CDM afforestation and reforestation project implementation asa lack of "financial, administrative and governance issues". Successful projects were found to possess attributes such as secured initial funding, backing from organizations with relevant experience, occurring on private land (and therefore by passing any land right tenure contestation) and lastly proceeds from the market based mechanism being reinvested back into the community. The CDM programme has been successful as a large number of projects have been energy related and implemented in the emerging economies where infrastructure already exists [28] [37]. However, the CDM programme 
has not been successful in the least developing economies (LDCs) owing to the poor infrastructure present [2] [37]. Conversely, REDD+ projects have been implemented in the LDCs as the presence of existing infrastructure is not required. Even though there are various implementation differences between CDM and REDD+, there is much that can be learnt from the CDM programme to enhance and streamline the structure, implementation and efficiency of REDD+.

CDM and REDD+ are similar in their processes as they both require projects to illustrate additionality [38]. At times it has been suggested that the CDM programme falls short of stringently evaluating whether additionality is present and projects where likely to go ahead in any case [2]. Also, the CDM programme has been questioned in numerous studies in its ability to promote sustainability while delivering Certifiable Emission Reductions [39]. Therefore, the argument may exist for the exclusion of the CDM programme in a future climate international environmental agreement as it lacks effectiveness in terms of implementation and outcomes. Lastly, even though we now have technological and methodological approaches to rectify to current flaws of the mechanism; it is questionable whether they will be implemented [40]. As mentioned in previous sections, CDM projects that promote afforestation and reforestation can easily be disrupted by natural causes (forest fires, drought and floods) and by anthropogenic activities (logging, degradation and poor management) [27] [28]. Carbon markets account for $\$ 142$ billion which are actively traded [41]. A REDD+ scheme that is market based can allow for more financial transfer to gain carbon credits which can be traded and this can allow other industrialized countries to enter the market and not only the extremely rich countries. Also, the initializing of a REDD+ market based scheme would generate income of approximately \$7 billion dollars a year would be reinvested into the model and provide more protection of forests and social upliftment. Also, a purely fund based mechanism costs between $\$ 2$ and $\$ 28$ billion dollars a year-if a market based system can provide additional funding it may make it more resilient in the long term (particularly against recession when funding may be reduced) [29]. Also, the additional funding allows for increased conservation and protection of other vegetation types not only forest and could enhance the mitigation potential of the REDD+ scheme [9].

\section{REDD+ and Indigenous Populations}

REDD+ as a mechanism primarily operates between developing and developed countries where the policies are structured to promote benefits in the poorest countries [16] [42]. According to the Forest Peoples Programme (2012) 300 to 350 million people live within or are dependent upon forests, globally [43]. As mentioned in Section 2, REDD+ is still principally a carbon emission reduction mechanism however if it is to be included in a post Kyoto agreement then the co-benefit of poverty reduction must be addressed within the structure [33]-[35]. Pagiola et al. [44] aimed to evaluate the relation between poverty and REDD+ where there are three fundamental concerns. The REDD+ scheme needs to identify whether rural livelihoods are indeed "poor" and how many participants are "poor" [45]. Secondly, what inhibits poor people from being integrated into a REDD+ scheme and lastly what are the impacts of a REDD+ scheme on the poor? Other concerns of REDD+ on livelihoods include, whether benefits or losses can be sustainable in the long term and whether REDD+ can be implemented with the legal framework of indigenous populations [46].

It is imperative that local communities are integrated into REDD+ scheme if it is to be successful. REDD+ schemes implemented at a national level could be resisted by local communities if benefits do not filter down to the local level [47]. Therefore it is important the REDD+ schemes monitor local community benefits while preventing corruption at a government level [48]. However, even though community involvement is important, defined resource rights are imperative if illegal exploitation of forest is to be prevented and those accountable held responsible [49]. In several African countries, tenure rights are not well defined [46] in these scenarios; economic incentives need to be especially strong and well defined to be inclusive where all financial leakage may occur. Additionally, small scale agriculture is not the primary driver in promoting deforestation and degradation however increased population growth could make this a concern in the future [50].

There are five major requirements for good implementation of REDD+ PES schemes within rural communities: These can be summarized as local assistance for REDD+ schemes, community involvement in reforming REDD+ structure to change property rights, transparency and accountability as to how profits of the REDD+ scheme are managed, open formalized forums to all rural community members to voice concerns (without fear of being ostracized) and lastly mechanisms that allow for adaptive management in response to changes in the REDD+ scheme [46]. Local involvement in a REDD+ scheme will promote more trust of the system and "free 
and prior informed consent” by management will create a sense of inclusion with rural communities which can only aid the REDD+ schemes being well implemented [47]. Citizen participation to reform property rights and REDD+ structure is imperative for projects to overcome the legal jurisdiction of implementation [49]. Creating participation by forums for dialogue can provide more effective functioning of the PES. Rural community forums where participants can voice their concerns is perhaps the most important part of reforming the institutional structures of REDD+. A scheme that does not allow for open dialogue with the rural communities (who are directly affected by a REDD+ scheme) will surely fail as it discounts the accountability of the management of REDD+ scheme. Lastly, the REDD+ scheme needs to be adaptive in that it must allow for changes to occur within a reasonable timeframe [46]. REDD+ schemes need to be resistant to change as a failure of the system could lead to the disintegration of the entire system and hence carbon emissions that are difficult to recover.

\section{Conclusion}

From previous paragraphs, the evidence is quite overwhelming that forest protection needs to be included a post Kyoto agreement IEA. Prior to addressing procedural concerns of the mechanism, it firstly needs to be determined whether REDD+ will be primarily be a carbon sequestration mechanism or will it be a mechanism that encompasses protection of ecosystems as a whole. If the REDD+ mechanism is to be implemented as a carbon mitigation tool, then it is necessary that a complementary biodiversity PES system be introduced to offset the effects biodiversity loss. Secondly, there are two interconnected issues: timeframe of implemented projects within a REDD+ framework and the availability of finance. REDD+ projects have to be long term investments simply because their goals can be rapidly undone by harvesting in a time period that is not under "REDD+" protection. Gaining finance, either through funding by the UNFCCC (if implemented in a future IEA) or voluntary bilateral agreements needs to be sustainable in the long term. Therefore, if finance cannot be guaranteed, then there needs to be serious consideration that REDD+ be altered structurally from a fund based mechanism to a market based mechanism so that it can generate more capital to make the "system" self-sustaining. This is integral as it is the finance availability that will determine how other concerns are addressed in the REDD+ framework. Leakage that is, carbon emissions from other sources as a result of behavioural changes from forest protection, and all integrated levels of deforestation in different states into one system are all a function of finance. Lastly, and perhaps the most important concern from a human rights perspective, is how indigenous populations who live in forests are integrated into the REDD+ scheme. Ultimately, people who live in forests, have the most power to stop a REDD+ project from working efficiently. If their leakage of carbon can be mitigated through finance if they are not allowed to extract resources from forests, then the REDD+ scheme will surely be more effective. Lastly, if the indigenous populations can be included into the decision making and operational running of REDD+ projects it will could create more trust, accountability, transparency and address all pillars of sustainability while addressing some present concerns of REDD+.

\section{References}

[1] UNFCCC (2013) REDD Web Platform. http://unfccc.int/methods/redd/redd_web_platform/items/4531.php

[2] Venter, O. and Koh, L.P. (2012) Reducing Emissions from Deforestation and Forest Degradation (REDD+): Game Changer or Just Another Quick Fix? Annals of the New York Academy of Sciences, 1249, 137-150. http://dx.doi.org/10.1111/j.1749-6632.2011.06306.x

[3] Pistorius, T. (2012) From RED to REDD+: The Evolution of a Forest-Based Mitigation Approach for Developing Countries. Current Opinion in Environmental Sustainability, 4, 638-645. http://dx.doi.org/10.1016/j.cosust.2012.07.002

[4] Chhatre, A., Lakhanpal, S., Larson, A.M., Nelson, F., Ojha, H. and Jagdeesh, R. (2012) Social Safeguards and CoBenefits in REDD+: A Review of the Adjacent Possible. Current Opinion in Environmental Sustainability, 4, 654-660. http://dx.doi.org/10.1016/j.cosust.2012.08.006

[5] Corbera, E. and Schroeder, H. (2012) Governing and Implementing REDD+. Environmental Science \& Policy, 14, 8999. http://dx.doi.org/10.1016/j.envsci.2010.11.002

[6] Harvey, C.A., Dickson, B. and Kormos, C. (2010) Opportunities for Achieving Biodiversity Conservation through REDD. Conservation Letters, 3, 53-61. http://dx.doi.org/10.1111/j.1755-263X.2009.00086.x

[7] Isenberg, J. and Potvin, C. (2010) Financing REDD in Developing Countries: A Supply and Demand Analysis. Climate Policy, 10, 216-231. http://dx.doi.org/10.3763/cpol.2008.0604 
[8] Cerbu, G.A., Swallow, B.M. and Thompson, D.Y. (2011) Locating REDD: A Global Survey and Analysis of REDD Readiness and Demonstration Activities. Environmental Science \& Policy, 14, 168-180. http://dx.doi.org/10.1016/j.envsci.2010.09.007

[9] IIED (2009) REDD: Protecting Climate Forests and Livelihoods. http://www.iied.org/redd-protecting-climate-forests-livelihoods

[10] UNCSD (2012) Green Jobs and Social Inclusion. Rio Di Janerio, Issue Brief, No. 7.

[11] Madeira, E.C.M. (2008) Policies to Reduce Emissions from Deforestation and Degradation (REDD) in Developing Countries: An Examination of the Issues Facing the Incorporation of REDD into Market-Based Climate Policies. Resource for the Future, Washington DC.

[12] Hartley, M.J. (2002) Rationale and Methods for Conserving Biodiversity in Plantation Forests. Forest Ecology and Management, 155, 81-95. http://dx.doi.org/10.1016/S0378-1127(01)00549-7

[13] Licata, J.A., Gyenge, J.E., Fernandez, M.E., Schlichter, T.M. and Bond, B.J. (2007) Increased Water Use by Ponderosa Pine Plantations in Northwestern Patagonia, Argentina Compared with Native Forest Vegetation. Forest Ecology and Management, 255, 753-764. http://dx.doi.org/10.1016/j.foreco.2007.09.061

[14] De Sy, V., Herold, M., Achard, F., Asner, G.P., Held, A., Kellndorfer, J. and Verbesselt, J. (2012) Synergies of Multiple Remote Sensing Data Sources for REDD+ Monitoring. Current Opinion in Environmental Sustainability, 4, 696706. http://dx.doi.org/10.1016/j.cosust.2012.09.013

[15] Herold, M. and Skutsch, M. (2011) Monitoring, Reporting and Verification for National REDD+ Programmes: Two Proposals. Environmental Research Letters, 6, 1-10. http://dx.doi.org/10.1088/1748-9326/6/1/014002

[16] Corbera, E., Estrada, M., May, P., Navarro, G. and Pacheco, P. (2011) Rights to Land, Forests and Carbon in REDD+: Insights from Mexico, Brazil and Costa Rica. Forests, 2, 301-342.

[17] Kotak, T. (2013) The REDD+ Programme: Effects on Governance Theory, Market Theory, and a Post-Kyoto World.

[18] Venter, O., Laurance, W.F., Iwamura, T., Wilson, K.A., Fuller, R.A. and Possingham, H.P. (2009) Harnessing Carbon Payments to Protect Biodiversity. Science, 326, 1368-1368. http://dx.doi.org/10.1126/science.1180289

[19] Jindal, R., Swallow, B. and Kerr, J. (2008) Forestry-Based Carbon Sequestration Projects in Africa: Potential Benefits and Challenges. Natural Resources Forum, Wiley Online Library.

[20] Sasaki, N. and Putz, F.E. (2009) Critical Need for New Definitions of "Forest” and "Forest Degradation" in Global Climate Change Agreements. Conservation Letters, 2, 226-232.

[21] Saatchi, S.S., Harris, N.L., Brown, S., Lefsky, M., Mitchard, E.T.A., Salas, W., Zutta, B.R., Beurmann, W., Lewis, S.L., Hagen, S., Petrova, S., White, L., Silman, M. and Morei, A. (2011) Benchmark Map of Forest Carbon Stocks in Tropical Regions across Three Continents. Proceedings of the National Academy of Sciences, 108, 9899-9904. http://dx.doi.org/10.1073/pnas.1019576108

[22] Scheffer, M. and Carpenter, S.R. (2003) Catastrophic Regime Shifts in Ecosystems: Linking Theory to Observation. Trends in Ecology and Evolution, 18, 648-656. http://dx.doi.org/10.1016/j.tree.2003.09.002

[23] Thompson, I., Mackey, B., McNulty, S. and Mosseler, A. (2009) Forest Resilience, Biodiversity, and Climate Change. A Synthesis of the Biodiversity/Resilience/Stability Relationship in Forest Ecosystems. Technical Series No. 43, Secretariat of the Convention on Biological Diversity, Montreal, 67 p.

[24] Erskine, P.D., Lamb, D. and Bristow, M. (2006) Tree Species Diversity and Ecosystem Function: Can Tropical Multi-Species Plantations Generate Greater Productivity? Forest Ecology and Management, 233, 205-210. http://dx.doi.org/10.1016/j.foreco.2006.05.013

[25] Cannell, M.G. (1999) Environmental Impacts of Forest Monocultures: Water Use, Acidification, Wildlife Conservation, and Carbon Storage. New Forests, 17, 239-262. http://dx.doi.org/10.1023/A:1006551018221

[26] Stickler, C.M., Nepstad, D.C., Coe, M.T., McGrath, G., Rodrigues, H.O., Walker, W.S., Soares-Filho, B.S. and Davidson, E.A. (2009) The Potential Ecological Costs and Co-Benefits of REDD: A Critical Review and Case Study from the Amazon Region. Global Change Biology, 15, 2803-2824. http://dx.doi.org/10.1111/j.1365-2486.2009.02109.x

[27] Pistorius, T., Schmitt, C., Benick, D., Entenmann, S. and Reinecke, S. (2011) Greening REDD+-Challenges and Opportunities for Integrating Biodiversity Safeguards at and across Policy Levels. German Journal of Forest Science, 182, 82-98.

[28] Fry, I. (2008) Reducing Emissions from Deforestation and Forest Degradation: Opportunities and Pitfalls in Developing a New Legal Regime. Review of European Community \&International Environmental Law, 17, 166-182. http://dx.doi.org/10.1111/j.1467-9388.2008.00597.x

[29] Lederer, M. (2011) From CDM to REDD+-What Do We Know for Setting up Effective and Legitimate Carbon Governance? Ecological Economics, 70, 1900-1907. http://dx.doi.org/10.1016/j.ecolecon.2011.02.003

[30] Merger, E., Dutschke, M. and Verchot, L. (2011) Options for REDD+ Voluntary Certification to Ensure Net GHG 
Benefits, Poverty Alleviation, Sustainable Management of Forests and Biodiversity Conservation. Forests, 2, 550-577. http://dx.doi.org/10.3390/f2020550

[31] Spergel, B. and Wells, M. (2009) Conservation Trust Funds as a Model for REDD+ National Financing. Center for International Forestry Research (CIFOR), Bogor.

[32] Halpern, B.S., Pyke, C.R., Fox, H.E., Haney, J.C., Schlaepfer, M.A. and Zaradic, P. (2006) Gaps and Mismatches between Global Conservation Priorities and Spending. Conservation Biology, 20, 56-64. http://dx.doi.org/10.1111/j.1523-1739.2005.00258.x

[33] Eliasch, J. (2008) Climate Change: Financing Global Forests-The Eliasch Review. Earthscan, London and Sterling. http://www.official-documents.gov.uk/document/other/9780108507632/9780108507632.pdf

[34] Stern, N. (2008) The Economics of Climate Change. American Economic Review, 98, 1-37. http://dx.doi.org/10.1257/aer.98.2.1

[35] Reinecke, S., Pistorius, T. and Pregernig, M. (2014) UNFCCC and the REDD+ Partnership from a Networked Governance Perspective. Environmental Science \& Policy, 35, 30-39. http://dx.doi.org/10.1016/j.envsci.2012.09.015

[36] Thomas, S., Dargusch, P., Harrison, S. and Herbohn, J. (2010) Why Are There So Few Afforestation and Reforestation Clean Development Mechanism Projects? Land Use Policy, 27, 880-887. http://dx.doi.org/10.1016/j.landusepol.2009.12.002

[37] Lloyd, B. and Subbarao, S. (2009) Development Challenges under the Clean Development Mechanism (CDM)—Can Renewable Energy Initiatives Be Put in Place before Peak Oil? Energy Policy, 37, 237-245. http://dx.doi.org/10.1016/j.enpol.2008.08.019

[38] Bhullar, L. (2013) REDD+ and the Clean Development Mechanism: A Comparative Perspective. International Journal of Rural Law and Policy.

[39] Sutter, C. and Parreño, J.C. (2007) Does the Current Clean Development Mechanism (CDM) Deliver Its Sustainable Development Claim? An Analysis of Officially Registered CDM Projects. Climatic change, 84, 75-90. http://dx.doi.org/10.1007/s10584-007-9269-9

[40] Schlamadinger, B., Johns, T., Ciccarese, L., Braun, M., Sato, A., Senyaz, A., Stephens, P., Takahashi, M. and Zhang, X. (2007) Options for Including Land Use in a Climate Agreement Post-2012: Improving the Kyoto Protocol Approach. Environmental Science \& Policy, 10, 295-305. http://dx.doi.org/10.1016/j.envsci.2006.12.004

[41] Linacre, N., Kossoy, A. and Guigon, P. (2011) State and Trends of the Carbon Market 2011.

[42] Groom, B. and Palmer, C. (2012) REDD+ and Rural Livelihoods. Biological Conservation, 154, 42-52. http://dx.doi.org/10.1016/j.biocon.2012.03.002

[43] Food and Agriculture Organization (1998) Biodiversity for Food and Agriculture. http://www.fao.org/sd/epdirect/EPre0043.htm

[44] Pagiola, S., Arcenas, A. and Platais, G. (2005) Can Payments for Environmental Services Help Reduce Poverty? An Exploration of the Issues and the Evidence to Date from Latin America. World Development, 33, 237-253. http://dx.doi.org/10.1016/j.worlddev.2004.07.011

[45] Urban, F. (2010) The MDGs and Beyond: Can Low Carbon Development Be Pro-Poor? IDS Bulletin, 41, 92-99. http://dx.doi.org/10.1111/j.1759-5436.2010.00109.x

[46] Lawlor, K., Weinthal, E. and Olander, L. (2010) Institutions and Policies to Protect Rural Livelihoods in REDD+ Regimes. Global Environmental Politics, 10,1-11. http://dx.doi.org/10.1162/GLEP_a_00028

[47] Lyster, R. (2011) REDD+, Transparency, Participation and Resource Rights: The Role of Law. Environmental Science \& Policy, 14, 118-126. http://dx.doi.org/10.1016/j.envsci.2010.11.008

[48] Angelsen, A. and Brockhaus, M. (2009) Realising REDD+: National Strategy and Policy Options. CIFOR, Bogor.

[49] Palmer, C. (2011) Property Rights and Liability for Deforestation under REDD+: Implications for "Permanence" in Policy Design. Ecological Economics, 70, 571-576. http://dx.doi.org/10.1016/j.ecolecon.2010.10.011

[50] Rudel, T.K., Defries, R., Asner, G.P. and Laurance, W.F. (2009) Changing Drivers of Deforestation and New Opportunities for Conservation. Conservation Biology, 23, 1396-1405. http://dx.doi.org/10.1111/j.1523-1739.2009.01332.x 